\title{
Mice Deficient in Cyp4a14 Have An Increased Number of Goblet Cells and Attenuated Dextran Sulfate Sodium- Induced Colitis
}

\author{
Qingxia Xuan a,b Yunfeng Zhou ${ }^{c}$ Binbin Tan ${ }^{d}$ Zhongyue Xiao ${ }^{e} \quad$ Shizhen Donga,f \\ Faliang Daia Lei Gao ${ }^{a}$ Tengfei Guo ${ }^{a}$ Pan Chen ${ }^{a}$ Jie Sun ${ }^{a}$ Dandan Fenga \\ Jianjun Jin ${ }^{\mathrm{a}}$ Fong-Fong Chu ${ }^{\mathrm{a}, \mathrm{h}}$ Qiang Gao ${ }^{\mathrm{a}, \mathrm{i}}$
}

aDepartment of Gastroenterology and Hepatology, The First Affiliated Hospital and College of Clinical

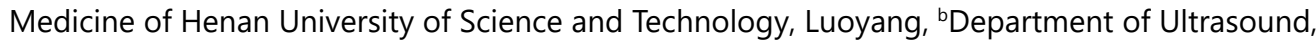
Women and Children Health Care Center of Luoyang, 'Department of Physiology, Medical Research Center, Shenzhen University Health Science Center, Shenzhen, dDepartment of Pharmacology, School of Basic Medical Sciences, Shenzhen University Health Science Center, Shenzhen, eDepartment of Oncology, The First Affiliated Hospital and College of Clinical Medicine of Henan University of Science and Technology, Luoyang, fDepartment of Clinical Laboratory, The First Affiliated Hospital and College of Clinical Medicine of Henan University of Science and Technology, Luoyang, 9Department of Biochemistry and Molecular Biology, Medical Research Center, Shenzhen University Health Science Center, Shenzhen, China, hepartment of Cancer Genetics and Epigenetics, Beckman Research Institute of the City of Hope, Duarte, USA, 'Department of Gastroenterology and Hepatology, Beijing Rehabilitation Hospital, Capital Medical University, Beijing, China

\section{Key Words}

Colitis • Cyp4a14 • Goblet cells • NADPH oxidase

\begin{abstract}
Background/Aims: Cyp4a14 is a member of cytochrome P450 (Cyp450) enzyme superfamily that possesses NADPH monooxygenase activity, which catalyzes omega-hydroxylation of medium-chain fatty acids and arachidonic acid. Study suggests that down-regulation of Cyp4a14 has an anti-inflammatory response in intestine. The present study was to test the function of Cyp4a14 in dextran sulfate sodium (DSS)-induced colitis. Methods: Female Cyp4a14-knockout (KO) and wild-type (WT) mice were treated with DSS for 6 days to induce colitis. The colon of mice was histologically observed by hematoxylin and eosin (H\&E) and periodic acid Schiff (PAS) staining. The serum malondialdehyde (MDA), an endogenous indicator of oxidative stress, was chemically measured. Proinflammatory and NADPH oxidase




\section{Cellular Physiology Cell Physiol Biochem 2018;50:2272-2282 \begin{tabular}{ll|l} 
and Biochemistry & $\begin{array}{l}\text { DOl: 10.1159/000495087 } \\
\text { Published online: 13 November } 2018\end{array}$ & $\begin{array}{l}\text { ( } 2018 \text { The Author(s). Published by S. Karger AG, Basel } \\
\text { www.karger.com/cpb }\end{array}$ \\
\cline { 2 - 3 }
\end{tabular} \\ Xuan et al.: Role of Cyp4a14 in Colitis}

genes were examined by quantitative polymerase chain reaction (qPCR). Results: Cyp4a14-KO mice had a significantly higher number of goblet cells in the colon and were more resistant to DSS-induced colitis compared with the WT mice. The DSS-treated KO mice had lower levels of MDA. Consistent with the milder inflammatory pathological changes, DSS-treated KO mice had lower levels of IL-1 $\beta$, IL- 6 and TNF- $\alpha$ mRNA in the liver and the colon. Moreover, the colon of DSS-treated Cyp4a14-KO and WT mice had higher mRNA levels of two members of NADPH oxidases, Nox2 and Nox4, suggesting that both Nox2 and Nox4 are inflammatory markers. By contrast, DSS-treated WT and KO mice had drastically decreased epithelium-localized Nox1 and dual oxidase (Duox) 2 mRNA levels, coinciding with the erosion of the mucosa induced by DSS. Conclusion: These results suggests a hypothesis that the increased goblet cell in the colon of Cyp4a14-KO mice provides protection from mucosal injury and Cyp4a14-increased oxidative stress exacerbates DSS-induced colitis. Therefore, Cyp4a14 may represent a potential target for treating colitis.

(C) 2018 The Author(s)

Published by S. Karger AG, Basel

\section{Introduction}

Inflammatory bowel disease (IBD) is comprised of ulcerative colitis and Crohn's disease. IBD is a refractory condition characterized by chronic inflammation involving ulcers and mucosal erosion of the lower gastrointestinal (GI) tract [1]. Although the exact causes of IBD remain unclear, multifactorial mechanisms, including genetics, immunity, microbiome and environment, contribute to the pathogenesis of IBD [2]. A variety of inflammatory mediators, such as cytokines, growth factors, GI hormones and enzymes producing oxidative stress and lipid peroxidation, are involved in the pathogenesis of IBD [3]. The colon is highly enriched in goblet cells that secrete mucus, primarily mucin-2 (Muc-2), to form a protective barrier against colonization and invasion of luminal microbes [4]. Mice with disrupted Muc-2 gene expression may develop spontaneous colitis and are susceptible to colon cancer development $[5,6]$. Decreased goblet cell numbers have been associated with active Crohn's disease and ulcerative colitis in humans [7].

Cytochrome P450s (CYPs) are members of a superfamily of heme proteins, which play a key role in the redox metabolism of endogenous and exogenous molecules [8]. Some CYPs mediate the process of inflammation via converting fatty acids to pro- or anti-inflammatory mediators $[9,10]$. The human or rodent CYP4A monooxygenases catalyze the $\omega$-hydroxylation of medium-chain fatty acids and arachidonic acid $[11,12,13]$. CYP4As are involved in the pathogenesis of inflammation, hypertension and cancer [14]. While humans only have one functional CYP4A11 gene in CYP4A family [15], mice have four, namely Cyp4a10,12a, 12b and 14 , which are predominantly expressed in the liver and kidney [16, 17]. Under inflammatory conditions, the expression of CYPs tends to be suppressed [18]. In dextran sulfate sodium (DSS)-induced colitis, the levels of Cyp4a10 and Cyp4a14 mRNA and Cyp4a protein were shown downregulated in the liver [19]. Similarly, in Citrobacter rodentium-induced mouse colitis, both Cyp4a10 and Cyp4a14 mRNA and protein levels were downregulated in the liver and kidney [12, 20, 21]. The fact that Cyp4a10- or Cyp4a14-knockout (KO) mice exhibited attenuated colitis induced by $C$. rodentium infection also suggests that down-regulation of Cyp4a gene expression is an anti-inflammatory response. The aim of the present study was to test the function of Cyp4a14 in DSS-induced colitis.

Cyp4a14 is a major enzyme that induces lipid peroxidation and lipid uptake in the liver $[13,22]$; thus, it contributes to hepatic steatosis and fibrosis in mice fed with a high-fat diet or a methionine-and-choline-deficient diet. 20-Hydroxyeicosatetraenoic acid (20-HETE) is one of the primary eicosanoids metabolized by the CYP4A subfamily and can induce the expression of the gp91 and p22phox subunits of Nox2, a member of NADPH oxidase (NOX, Nox in animal) in cardiomyocytes [23, 24]. Since oxidative stress clearly plays a key role in the pathogenesis of IBD, as shown by spontaneous ileocolitis developing in mice deficient in antioxidant enzymes $[25,26]$, we also evaluated the effect of Cyp4a14 on several members 


\section{Cellular Physiology Cell Physiol Biochem 2018;50:2272-2282 \begin{tabular}{ll|l} 
and Biochemistry & $\begin{array}{l}\text { DOl: 10.1159/000495087 } \\
\text { Published online: 13 November } 2018\end{array}$ & $\begin{array}{l}\text { ( } 2018 \text { The Author(s). Published by S. Karger AG, Basel } \\
\text { www.karger.com/cpb }\end{array}$ \\
\cline { 2 - 3 }
\end{tabular} \\ Xuan et al.: Role of Cyp4a14 in Colitis}

of Nox in the mouse colon. The NADPH oxidase family has 7 members in humans, namely NOX1-5 and dual oxidases (DUOX)-1 and -2 [27]. Mice express all these members except Nox 5 with four members expressed in the colon. NOX1 is highly expressed in the crypt epithelium and plays a role in physiological and inflammatory processes, as well as tissue repair in the colon $[28,29,30]$. DUOXs may play an essential role in host defense against microbes in the GI and respiratory epithelium $[31,32]$. NOX2 is present in phagocytes and is crucial for antimicrobial defense [33, 34]; NOX4 is abundant in the kidney and is involved in the pathogenesis of inflammation and colon cancer [35, 36].

In this study, it was confirmed that Cyp4a14 promotes inflammation in DSS-induced colitis. Mice with disrupted Cyp4a14 gene expression had attenuated inflammatory responses to DSS treatment, exhibiting decreased levels of lipid peroxidation in the plasma and a higher number of goblet cells in the colon compared with wild-type (WT) mice. Our results suggest that hepatic Cyp4a14 increases systemic lipid peroxidation and exacerbates DSS-induced colon tissue injury. Therefore, Cyp4a14 may represent a potential target for the treatment of colitis.

\section{Materials and Methods}

\section{Animal experimental procedures}

WT and Cyp4a14 KO mice on a 129/SvJ background originally generated by J Capdevila (Vanderbilt University, USA) [37], were kindly provided by YF Zhou (Shenzhen University, China) and housed at the Animal Center of the First Affiliated Hospital of Henan University of Science and Technology. The mice were kept under a 12-hour light/dark cycle and had free access to water and food. The genotype of Cyp4a14KO mice was confirmed as previously description [38]. Considering the differential gender-dependent expression of Cyp4a14 and its phenotypic sequelae [37], only female mice were studied here since Cyp4a14 is female-predominant in the liver [13]. A total of 40 Cyp4a14-KO and WT mice, aged 6-8 weeks and weighing 18-25 g, were divided into four groups (10 mice per group) as follows: i) Control WT, ii) Control KO, iii) DSS-treated WT and iv) DSS-treated KO. The DSS-treated mice were administered sterilized 3.0\% DSS (36-50 kDa molecular weight, MP Biomedicals, USA) in Millipore purified water, while the control mice were only given water. Mouse body weight, stool consistency and presence of rectal bleeding were assessed. The disease activity index (DAI) score, graded on a scale of 0 to 4 , was slightly modified from a previously published scoring system [39]. Mice losing $\geq 20 \%$ of their initial body weight were euthanized according to institutional guidelines. At 6 days post-DSS treatment, all mice were euthanized by cervical dislocation under diethyl ether anesthesia. The blood, colons and livers of mice were collected. The length of colons was measured. All experiments were performed according to the protocol approved by the Animal Experimentation Committee of The First Affiliated Hospital of Henan University of Science and Technology.

Analysis of mouse colon histology by hematoxylin and eosin (H\&E) and periodic acid Schiff (PAS) staining

Mouse colon histology was analyzed by H\&E and PAS staining. The sections from the distal third of colon were scored for inflammation pathology using an 11-point system modified from our previous studies $[40,41]$. These include lymphocyte and neutrophil infiltration (0-3 points), Paneth cell or goblet cell degranulation (0-2 points), epithelium reactivity, such as crypt distortion ( 0 -3 points) and inflammatory foci (0-3 points). The threshold for severe acute inflammation corresponds to a score of 6 points. PAS staining was also conducted on sections from the distal third of the colon using periodic acid solution and Schiff's reagents (cat. no. 395B, Sigma-Aldrich, USA). The number of goblet cells was obtained from a field counting 100 absorptive epithelial cells from the control mice, and five fields were selected from each mouse; the number of goblet cells in DSS-treated mice was only counted in five fields from each mouse due to the destruction of the epithelium and loss of absorptive cells. 


\section{Cellular Physiology Cell Physiol Biochem 2018;50:2272-2282 \begin{tabular}{l|l|l} 
and Biochemistry Published online: 13 November 2018 & $\begin{array}{l}\text { (c) } 2018 \text { The Author(s). Published by S. Karger AG, Basel } \\
\text { www.karger.com/cpb }\end{array}$ \\
\hline
\end{tabular}

\section{Determination of MDA levels in the serum}

Serum was separated from the blood by centrifugation for $10 \mathrm{~min}$ at $3,000 \mathrm{rpm}$ at $4^{\circ} \mathrm{C}$ and stored at $-80^{\circ} \mathrm{C}$ until analysis. The serum MDA levels were assessed using a MDA kit (Beyotime Biotechnology, Shanghai, China) reacting with thiobarbituric acid (TBA). The MDA concentration was calibrated using a standard curve using the MDA provided by the manufacturer.

\section{Quantitative polymerase chain reaction ( $q P C R$ )}

Total RNA was extracted from tissues treated with TRIzol Reagent (Invitrogen, USA), according to the manufacturer's instructions. Total RNA ( $2 \mu \mathrm{g}$ ) was used for cDNA synthesis. PrimeScript ${ }^{\mathrm{TM}}$ RT Master Mix was used in a $40-\mu \mathrm{l}$ reaction mixture, incubated at $37^{\circ} \mathrm{C}$ for $15 \mathrm{~min}, 85^{\circ} \mathrm{C}$ for $5 \mathrm{sec}$ and $4^{\circ} \mathrm{C}$ for $10 \mathrm{~min}$ to generate cDNA. qPCR was performed using an Applied Biosystems 7500 real-time PCR system (Life Technologies) in a 25- $\mu \mathrm{l}$ qPCR reaction mixture containing $2 \mu \mathrm{l}$ cDNA mixture, $12.5 \mu \mathrm{l}$ 2X SYBR Premix Ex TaqTMII (Takara, Japan), $8.5 \mu \mathrm{l} \mathrm{H} \mathrm{H}_{2} \mathrm{O}$ and $1 \mu \mathrm{M}$ primers. The PCR primers of Cyp4a14, pro-inflammatory cytokines and Noxs were purchased from Sangon Biotech Co., Ltd (Shanghai, China). The primer sequences are listed in Table 1 were designed by using Primer3.0 website [42]. The cDNA was amplified by incubation at $95^{\circ} \mathrm{C}$ for $30 \mathrm{sec}$, followed by 40 cycles at $95^{\circ} \mathrm{C}$ for $5 \mathrm{sec}, 58^{\circ} \mathrm{C}$ for $34 \mathrm{sec}$ and $95^{\circ} \mathrm{C}$ for $15 \mathrm{sec}$. As actin mRNA was not changed in Cyp4a14-KO and WT mice in this study (data not shown) therefore actin was used as an internal control. Each sample was analyzed in triplicate.

\section{Statistical analysis}

Data are reported as the mean \pm standard deviation. A two-way ANOVA test was used when comparing the means of normally distributed parametric data and a Mann-Whitney U test was performed when comparing non-parametric, not normally distributed data. SPSS 20.0 (Chicago, USA) was used for all statistical analyses.

Table 1. Primers sequence for quantitative real-time PCR

\begin{tabular}{|c|c|c|c|}
\hline mRNA & Gene & Primer sequence & Amplicon (bp) \\
\hline NM-008361.4 & IL-1 $\beta$ & $\begin{array}{l}\text { F: 5'-TGC CAC CTT TTG ACA GTG ATG - } 3^{\prime} \\
\text { R: 5'-AAG GTC CAC GGG AAA GAC AC - } 3^{\prime}\end{array}$ & 220 \\
\hline NM-031168.1 & IL-6 & $\begin{array}{l}\text { F: 5'-TGG TAC TCC AGA AGA CCA GAG - 3' } \\
\text { R: 5'-AAC GAT GAT GCA CTT GCA GA - 3' }\end{array}$ & 128 \\
\hline NM-013693.3 & TNF- $\alpha$ & $\begin{array}{l}\text { F: 5'-AGG GTC TGG GCC ATA GAA CT - } 3^{\prime} \\
\text { R: 5' - CCA CCA CGC TCT TCT GTC TAC - } 3^{\prime}\end{array}$ & 161 \\
\hline NM-172203.2 & Nox1 & $\begin{array}{l}\text { F: 5'-TTCCTCACTGGCTGGGATAG- 3' } \\
\text { R: 5'-AGTCCGAGGGCCACATAAGA- 3' }\end{array}$ & 189 \\
\hline NM-007807.5 & Nox2 & $\begin{array}{c}\text { F: } 5^{\prime}-\text { TGT TTT CAT TTC CTC ATC AGA AG-3' } \\
\text { R: } 5^{\prime} \text {-CCA ACC ACA CCA GAA TGA CA- } 3^{\prime}\end{array}$ & 132 \\
\hline NM-015760.5 & Nox4 & $\begin{array}{l}\text { F: 5'-TCT GGA AAA CCT TCC TGC TG- } 3^{\prime} \\
\text { R: 5'-CCG GCA CAT AGG TAA AAG GA- } 3^{\prime}\end{array}$ & 143 \\
\hline NM-177610.2 & Duox2 & $\begin{array}{l}\text { F: 5'-TGGTCCCAGCAATTATCTATG- } 3^{\prime} \\
\text { R: 5'- CCACTGCCCTGATTTGTACTC- } 3^{\prime}\end{array}$ & 155 \\
\hline NM-007393 & $\beta$-actin & $\begin{array}{c}\text { F: 5'-GGC TGT ATT CCC CTC CAT CG - 3' } \\
\text { R: 5'- CCA GTT GGT AAC AAT GCC ATG - 3' }\end{array}$ & 154 \\
\hline
\end{tabular}




\section{Results}

Mice deficient in Cyp4a14 had milder colitis induced by DSS compared with WT mice

DSS-treated WT mice exhibit suppressed hepatic Cyp4a14 gene expression [12]. To test whether Cyp4a14 monooxygenase exacerbates DSS-induced colitis, we compared the phenotypes between Cyp4a14-KO and WT mice. Both DSS-treated WT and KO mice started to show disease signs at day 3 , with lower water and food intake, weight loss, loose stool or diarrhea, and rectal bleeding (Fig. $1 \mathrm{~A}$ and B). However, the KO mice had a significantly lower disease activity index (DAI) at day 6. In addition, DSS-treated KO mice had a longer colon compared with the treated WT mice (Fig. 1C). As expected, the colons of untreated control Cyp4a14-KO and WT mice had similar lengths, and were both longer compared with those of the DSS-treated mice.

Cyp4a14-KO mouse colons had more goblet cells and milder DSS-induced colitis compared with the WT mice

On histological examination following staining with hematoxylin and eosin (H\&E) or periodic acid Schiff (PAS) reagents, the colons of Cyp4a14-KO mice had more goblet cells compared with WT mice in both the control and DSS-treated groups (Fig. 2A and B). The higher number of goblet cells may have protected KO mice from DSS-induced injury. DSS treatment caused extensive exfoliation of crypt epithelial cells, crypt destruction and loss and focal transmural inflammation in the colon (Fig. 2A). As expected, the pathological score in DSS-treated WT mouse colons was significantly higher compared with that in DSS-treated Cyp4a14-KO mice (Fig. 1D).

Cyp4a14-KO mice had lower levels of lipid peroxidation compared with WT mice with or without DSS treatment

Cyp4a14 is a major enzyme inducing hepatic lipid peroxidation and contributing to hepatic steatosis and fibrosis [13,22]. Cyp4a14 also promotes hypotension, suggesting that

Fig. 1. Comparison of DSS effect on Cyp4a14-KO with WT mice. (A) Body weight changes presented as the percentage of initial weight during the 6 day treatment. (B) Disease activity index (DAI) scored during the course of treatment. (C) Colon length measured at the end of 6 day treatment. Histological score determined on the H\&E-stained colon sections. The statistical comparisons were done on Day 6. The

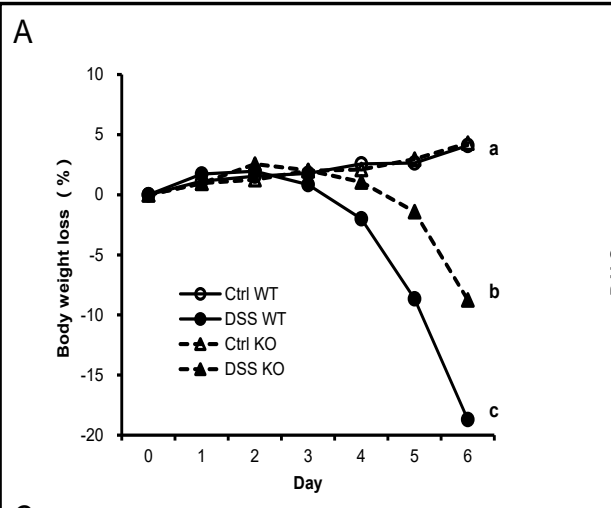

C

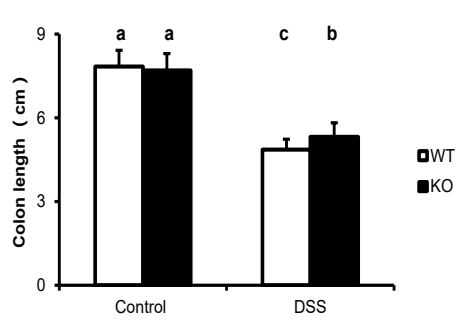

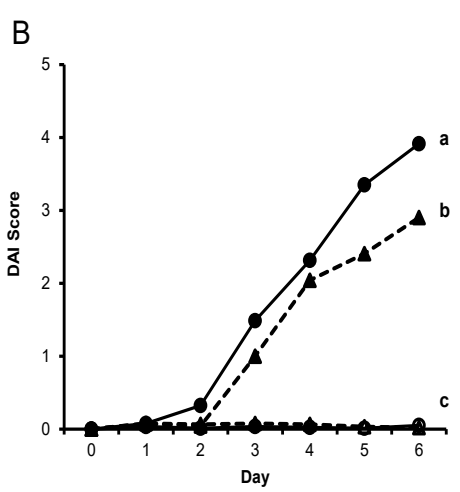

D

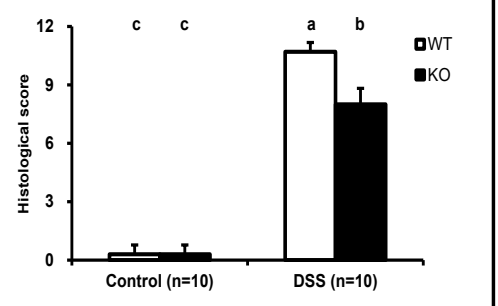

groups with different letters indicate that they are significantly different. The group with the letter a has a higher mean than the group with the letter $b$, which has a higher mean than the group with the letter c, i.e., $\mathrm{a}>\mathrm{b}>\mathrm{c}, \mathrm{P}<0.05$. 


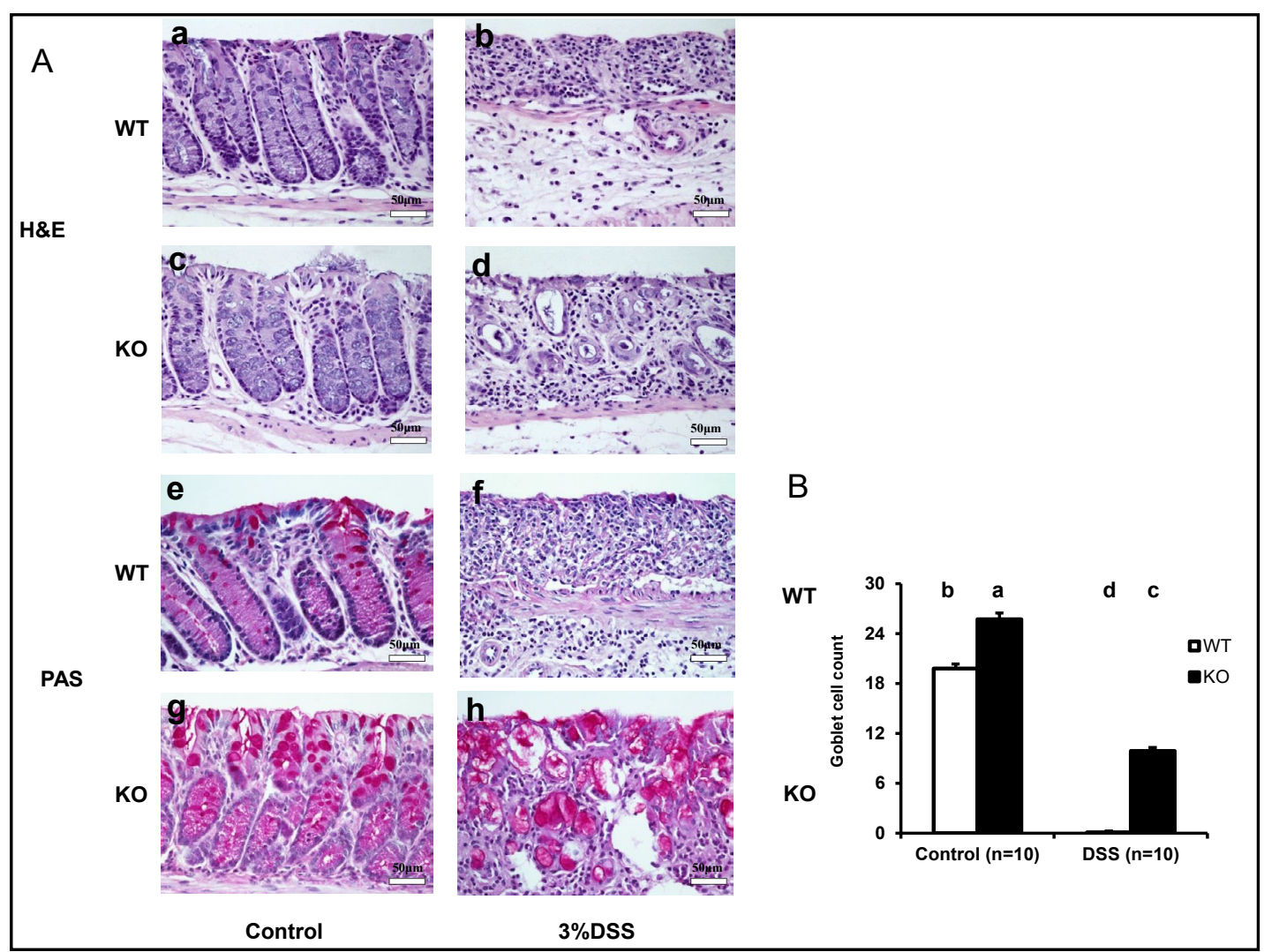

Fig. 2. Histology of mouse colon stained with H\&E and periodic acid Schiff (PAS) reagents. (A) Panels a-d are H\&E stained colon sections from WT control (a), WT DSS-treated (b), Cyp4a14 KO control (c) and KO DSStreated (d) mice. Analysis is shown in Fig. 1D. Panels e-h are PAS-stained colon sections from WT control (e), WT DSS-treated (f), KO control (g) and KO DSS-treated (h) mice. PAS stains carbohydrate as pink color. Magnification, $x 400$. (B) Goblet cell number analyzed on the PAS-stained sections. The groups with different letters indicate that the means are different, where $a>b>c>d, P<0.05$.

Fig. 3. Comparison of MDA levels between Cyp4a14KO and WT mice with and without DSS treatment. MDA levels were increased following DSS treatment. Cyp4a14-KO mice had lower MDA levels compared to WT mice with or without DSS treatment. The groups with different letters indicate that the means are different, where $\mathrm{a}>\mathrm{b}>\mathrm{c}>\mathrm{d}, \mathrm{P}<0.05$.

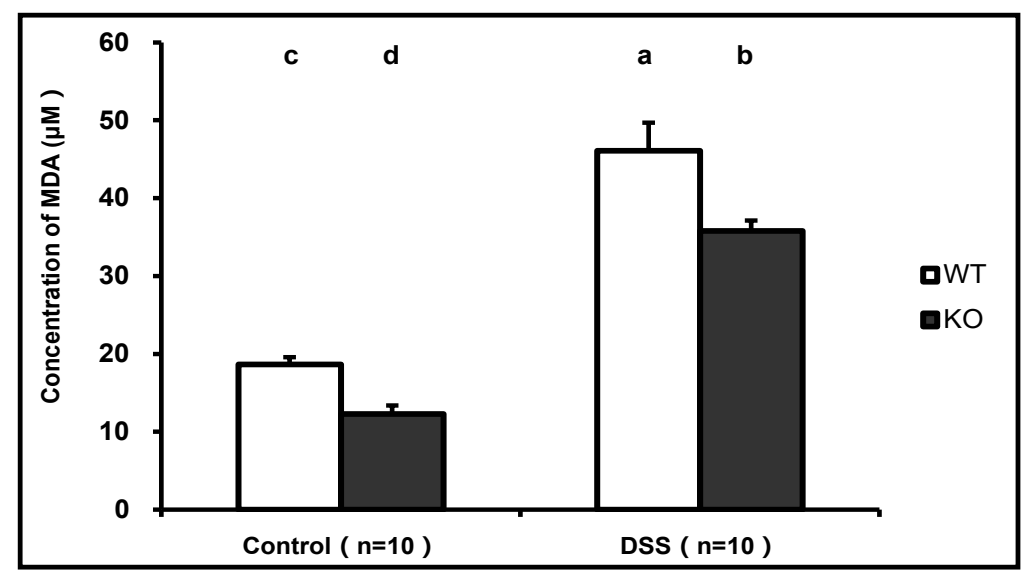

hepatic and renal monooxygenases have systemic effects [37]. We quantified systemic lipid peroxidation by analyzing the level of MDA in the serum. In both the control and DSS-treated groups, the sera of Cyp4a14-KO mice had a significantly lower level of MDA compared with WT mice (Fig. 3). The fact that DSS treatment drastically increased serum MDA levels in both Cyp4a14-KO and WT mice supports the hypothesis that colitis is associated with increased lipid peroxidation.

\section{KARGER}


Table 2. Cytokine mRNA levels in mouse colon and liver

\begin{tabular}{lcccccc}
\hline & \multicolumn{2}{c}{ IL-1 $\beta$} & \multicolumn{2}{c}{ IL-6 } & \multicolumn{2}{c}{ TNF- $\alpha$} \\
\hline & Colon & Liver & Colon & Liver & Colon & Liver \\
WT Ctrl & $1.0 \pm 0.1 \mathrm{~b}$ & $1.0 \pm 0.1^{\mathrm{c}}$ & $1.0 \pm 0.0^{\mathrm{c}}$ & $1.0 \pm 0.1^{\mathrm{c}}$ & $1.0 \pm 0.1^{\mathrm{c}}$ & $1.0 \pm 0.1^{\mathrm{b}}$ \\
KO Ctrl & $1.9 \pm 0.0 \mathrm{~b}$ & $1.1 \pm 0.1^{\mathrm{c}}$ & $0.8 \pm 0.0^{\mathrm{c}}$ & $1.1 \pm 0.1^{\mathrm{c}}$ & $0.9 \pm 0.1^{\mathrm{c}}$ & $0.9 \pm 0.1^{\mathrm{b}}$ \\
WT DSS & $286.0 \pm 144.7 \mathrm{a}$ & $8.2 \pm 1.7 \mathrm{a}$ & $103923.9 \pm 67037.9 \mathrm{a}$ & $84.6 \pm 16.2^{\mathrm{a}}$ & $6.2 \pm 0.6^{\mathrm{a}}$ & $2.4 \pm 0.2^{\mathrm{a}}$ \\
KO DSS & $211.4 \pm 49.1 \mathrm{a}$ & $3.1 \pm 0.2^{\mathrm{b}}$ & $7458.1 \pm 3053.5 \mathrm{~b}$ & $4.7 \pm 0.3 \mathrm{~b}$ & $2.7 \pm 0.2^{\mathrm{b}}$ & $3.7 \pm 0.2^{\mathrm{a}}$ \\
\hline
\end{tabular}

Fig. 4. Comparison of the mRNA levels of NADPH oxidase Nox1, Nox2, Nox4 and Duox2 in the colon and Cyp4a14 in the liver with or without DSS treatment. Comparison of the levels of Nox1, Nox2, Nox4 and Duox2 mRNA in the colon of Cyp4a14KO and WT mice with or without DSS treatment. Comparison of the mean was made for each gene individually. Comparison of the levels of Cyp4a14 mRNA in the liver of WT mice with and without DSS treatment. The groups with different letters have different means, where $\mathrm{a}>\mathrm{b}, \mathrm{P}<0.05$.

Cyp4a14-KO mice had lower levels of pro-inflammatory cytokine mRNAs in the colon and the liver after DSS treatment compared with WT mice

DSS treatment increased the mRNA levels of IL-1 $\beta$, IL- 6 and TNF- $\alpha$ in the liver and colon of Cyp4a14-KO and -WT mice (Table 2). The WT mice had higher levels of these proinflammatory cytokines in either the colon (TNF- $\alpha$ ), the liver (IL-1 $\beta$ ), or both (Il-6), compared with KO mice after DSS treatment. There was no difference in the liver and colon mRNA levels of these cytokines between untreated WT and KO mice. This result supports the fact that DSS-induced colitis is milder in Cyp4a14-KO compared with that in Cyp4a14-WT mice.

\section{CYP4A14 had a minimal effect on NADPH oxidase gene expression in the colon}

Cyp4a hydrolyzes arachidonic acid into 20-HETE, which induces the expression of the gp91 and p22phox subunits of Nox2in cardiomyocytes [23, 24]. Thus, the mRNA levels of Nox1, Nox2, Nox4 and Duox2 were also analyzed in the colons of Cyp4a14-KO and -WT mice. DSS treatment markedly decreased the mRNA levels of Nox1 and Duox2, two epitheliumspecific NADPH oxidases (Fig. 4A). This drastic decrease in epithelium-expressed Nox1 and Duox2 mRNA levels is likely due to the loss of colonic epithelium induced by DSS treatment. 


\section{Cellular Physiology Cell Physiol Biochem 2018;50:2272-2282 \begin{tabular}{ll|l} 
and Biochemistry & $\begin{array}{l}\text { DOl: 10.1159/000495087 } \\
\text { Published online: 13 November } 2018\end{array}$ & $\begin{array}{l}\text { ( } 2018 \text { The Author(s). Published by S. Karger AG, Basel } \\
\text { www.karger.com/cpb }\end{array}$ \\
\cline { 2 - 3 }
\end{tabular} \\ Xuan et al.: Role of Cyp4a14 in Colitis}

The mRNA levels of Nox2 and Nox4 were found to be the same in the colon compared between Cyp4a14-KO and WT mice with or without DSS treatment, suggesting that Cyp4a14 does not affect Nox2 or Nox4 gene expression in the colon (Fig. 4A). However, both Nox2 and Nox4 mRNAs were markedly elevated in the inflamed colon after DSS treatment. This finding suggests that both Nox 2 and Nox 4 are inflammatory markers expressed by non-epithelial cells.

Similar to other reports, the hepatic Cyp4a14 mRNA levels were decreased by more than 9-fold after DSS-treatment in the WT mice (Fig. 4B). As expected, Cyp4a14 mRNA expression was not detected in the colon (data not shown), as this gene is mainly expressed in the liver and kidney [16].

\section{Discussion}

In this study, it was demonstrated that mice deficient in Cyp4a14 developed milder DSSinduced colitis compared with WT mice. Cyp4a14 is predominantly expressed in the liver and kidney, and is a major enzyme involved in lipid peroxidation. Unlike other Cyp4a isozymes, Cyp4a14 does not catalyze arachidonic acid directly to produce 20-HETE, an inflammation promoter $[43,44,45,46]$. However, Cyp4a14 appears to induce Cyp4a10 and Cyp4a12 gene expression, which produce lipid peroxidation, since Cyp4a14-KO mouse liver exhibits significantly reduced mRNA levels of other Cyp4as [13]. The lipid peroxidation generated in the liver and kidney apparently has a systemic impact, affecting the colon, as well as other tissues, such as the cardiovascular and pulmonary systems [46, 47]. A systemic effect of lipid peroxidation induced by Cyp4a14 was also detected in the present study, as Cyp4a14-KO mice exhibited lower levels of plasma MDA, a stable product of lipid peroxidation, compared with WT mice with and without DSS treatment.

Mice deficient in Cyp4a14 also had more goblet cells in the colon compared with WT mice, which may also contribute to their resistance to DSS-induced colitis. To the best of our knowledge, this is the first time description of this phenomena. The increased goblet cells in the colon of these mice could be a consequence of a developmental effect of Cyp4a14 deficiency since from our study and others there is no direct evidence that Cyp4a14 has promotion function of proliferation of colonic goblet cell. Cyp4a14 not only plays an important role in lipid metabolism, but also indirectly leads to oxidative stress [48]. Cyp4a14-induced oxidative stress affects the redox-sensitive cell differentiation pathways in the intestinal epithelium. Other studies have demonstrated that decreased oxidative stress in Nox1KO mice (since Nox1 produces superoxide in the crypt epithelium) resulted in increased levels of goblet cells, presumably by modulating the Wnt/ $\beta$-catenin and Notch 1 signaling pathways, which regulate differentiation of epithelial cells into either absorptive enterocytes or secretory cells (such as goblet cells) [49]. Our results suggest a hypothesis that Cyp4a14generated oxidative stress affects colonic epithelial cell differentiation.

We also analyzed the effect of Cyp4a14 on the four members of the NADPH oxidase family in the colon. Evidently, Cyp4a14 does not affect Nox gene expression, since the mRNA levels of all four members, Nox1, Nox2, Nox4 and Duox2, were the same in the colon of both KO and WT mice, with and without DSS treatment. However, DSS markedly decreased the mRNA levels of Nox1 and Doux2, two epithelium-specific enzymes that are involved in the pathogenesis of IBD $[26,50]$. The downregulation of Nox1 and Duox2 gene expression is most likely due to the loss of epithelial cells. By contrast, Nox2 and Nox4 gene expression levels were markedly increased in inflamed colons. Since Nox2 is highly expressed in the inflammatory cells (neutrophils and monocytes), elevation of Nox2 mRNA level may simply reflect the increase in infiltrating inflammatory cells. The fact that Nox4 expression was also highly induced by DSS treatment suggests that it is also expressed in inflammatory or immune cells.

In conclusion, the present study suggests that hepatic or renal Cyp4a14 increased systemic lipid peroxidation, which exacerbated DSS-induced colitis. The Cyp4a14-KO mice

\section{KARGER}




\section{Cellular Physiology Cell Physiol Biochem 2018;50:2272-2282

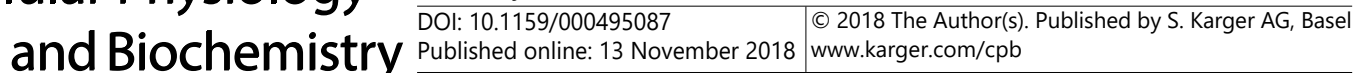 \\ Xuan et al.: Role of Cyp4a14 in Colitis}

were found to have more goblet cells in the colon, which provides additional protection from DSS-induced mucosal injury. The mechanism of consequent dual effects of lipid peroxidation and colon epithelial cell differentiation in Cpy4a14-deficient mice were worth to further study and might make Cyp4a14 an attractive therapeutic target for the treatment of colitis.

\section{Acknowledgements}

Xuan Q and Zhou Y contributed equally to this paper. This study was supported by the National Natural Science Foundation of China (grant no. 81370487 to Q. Gao; 81702104 to B. Tan), Natural Science Foundation of Guangdong Province of China (2018A030313134 to Y. Zhou; 2016A030313044 to B. Tan) and the Foundation of Shenzhen Basic Research Project (JCYJ20170818141928220 to Y. Zhou).

\section{Disclosure Statement}

The authors declare no conflict of interest.

\section{References}

1 Basson A, Trotter A, Rodriguez-Palacios A, Cominelli F: Mucosal Interactions between Genetics, Diet, and Microbiome in Inflammatory Bowel Disease. Front Immunol 2016;7:290.

2 Khor B, Gardet A, Xavier RJ: Genetics and pathogenesis of inflammatory bowel disease. Nature 2011;474:307-317.

3 Zhang YZ, Li YY: Inflammatory bowel disease: pathogenesis. World J Gastroenterol 2014;20:91-99.

$>4$ Birchenough GM, Johansson ME, Gustafsson JK, Bergström JH, Hansson GC: New developments in goblet cell mucus secretion and function. Mucosal Immunol 2015;8:712-719.

-5 Van der Sluis M, De Koning BA, De Bruijn AC, Velcich A, Meijerink JP, Van Goudoever JB, Büller HA, Dekker J, Van Seuningen I, Renes IB, Einerhand AW: Muc2-deficient mice spontaneously develop colitis, indicating that MUC2 is critical for colonic protection. Gastroenterology 2006;131:117-129.

6 Velcich A, Yang W, Heyer J, Fragale A, Nicholas C, Viani S, Kucherlapati R, Lipkin M, Yang K, Augenlicht L: Colorectal cancer in mice genetically deficient in the mucin Muc2. Science 2002;295:1726-1729.

7 Gersemann M, Becker S, Kübler I, Koslowski M, Wang G, Herrlinger KR, Griger J, Fritz P, Fellermann K, Schwab M, Wehkamp J, Stange EF: Differences in goblet cell differentiation between Crohn's disease and ulcerative colitis. Differentiation 2009;77:84-94.

8 Danielson PB: The cytochrome P450 superfamily: biochemistry, evolution and drug metabolism in humans. Curr Drug Metab 2002;3:561-597.

-9 Harvey RD, Morgan ET: Cancer, inflammation, and therapy: effects on cytochrome p450-mediated drug metabolism and implications for novel immunotherapeutic agents. Clin Pharmacol Ther 2014;96:449-457.

10 Christmas P: Role of Cytochrome P450s in Inflammation. Adv Pharmacol 2015;74:163-192.

-11 Okita RT, Okita JR: Cytochrome P450 4A fatty acid omega hydroxylases. Curr Drug Metab 2001;2:265-281.

12 Nyagode BA, Williams IR, Morgan ET: Altered inflammatory responses to Citrobacter rodentium infection, but not bacterial lipopolysaccharide, in mice lacking the Cyp4a10 or Cyp4a14 genes. Inflammation 2014;37:893-907.

13 Zhang X, Li S, Zhou Y, Su W, Ruan X, Wang B, Zheng F, Warner M, Gustafsson JÅ, Guan Y: Ablation of cytochrome P450 omega-hydroxylase 4A14 gene attenuates hepatic steatosis and fibrosis. Proc Natl Acad Sci U S A 2017;114:3181-3185.

14 Johnson AL, Edson KZ, Totah RA, Rettie AE: Cytochrome P450 omega-Hydroxylases in Inflammation and Cancer. Adv Pharmacol 2015;74:223-262. 


\section{Cellular Physiology Cell Physiol Biochem 2018;50:2272-2282

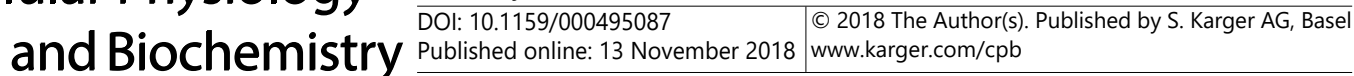 \\ Xuan et al.: Role of Cyp4a14 in Colitis}

15 Gainer JV, Bellamine A, Dawson EP, Womble KE, Grant SW, Wang Y, Cupples LA, Guo CY, Demissie S, O’Donnell CJ, Brown NJ, Waterman MR, Capdevila JH: Functional variant of CYP4A11

20-hydroxyeicosatetraenoic acid synthase is associated with essential hypertension. Circulation 2005;111:63-69.

-16 Zhang Y, Klaassen CD: Hormonal regulation of Cyp4a isoforms in mouse liver and kidney. Xenobiotica 2013;43:1055-1063.

17 Edson KZ, Rettie AE: CYP4 enzymes as potential drug targets: focus on enzyme multiplicity, inducers and inhibitors, and therapeutic modulation of 20-hydroxyeicosatetraenoic acid (20-HETE) synthase and fatty acid omega-hydroxylase activities. Curr Top Med Chem 2013;13:1429-1440.

-18 Aitken AE, Richardson TA, Morgan ET: Regulation of drug-metabolizing enzymes and transporters in inflammation. Annu Rev Pharmacol Toxicol 2006;46:123-149.

19 Chaluvadi MR, Nyagode BA, Kinloch RD, Morgan ET: TLR4-dependent and -independent regulation of hepatic cytochrome P450 in mice with chemically induced inflammatory bowel disease. Biochem Pharmacol 2009;77:464-471.

-20 Chaluvadi MR, Kinloch RD, Nyagode BA, Richardson TA, Raynor MJ, Sherman M, Antonovic L, Strobel HW, Dillehay DL, Morgan ET: Regulation of hepatic cytochrome P450 expression in mice with intestinal or systemic infections of citrobacter rodentium. Drug Metab Dispos 2009;37:366-374.

21 Nyagode BA, Lee CM, Morgan ET: Modulation of hepatic cytochrome P450s by Citrobacter rodentium infection in interleukin-6- and interferon-\{gamma\}-null mice. J Pharmacol Exp Ther 2010;335:480-488.

22 Leclercq IA, Farrell GC, Field J, Bell DR, Gonzalez FJ, Robertson GR: CYP2E1 and CYP4A as microsomal catalysts of lipid peroxides in murine nonalcoholic steatohepatitis. J Clin Invest 2000;105:1067-1075.

23 Han Y, Zhao H, Tang H, Li X, Tan J, Zeng Q Sun C: 20-Hydroxyeicosatetraenoic acid mediates isolated heart ischemia/reperfusion injury by increasing NADPH oxidase-derived reactive oxygen species production. Circ J 2013;77:1807-1816.

-24 Zeng Q, Han Y, Bao Y, Li W, Li X, Shen X, Wang X, Yao F, O’Rourke ST, Sun C: 20-HETE increases NADPH oxidase-derived ROS production and stimulates the L-type Ca2+ channel via a PKC-dependent mechanism in cardiomyocytes. Am J Physiol Heart Circ Physiol 2010;299:H1109-H1117.

25 Esworthy RS, Kim BW, Chow J, Shen B, Doroshow JH, Chu FF: Nox1 causes ileocolitis in mice deficient in glutathione peroxidase-1 and -2. Free Radic Biol Med 2014;68:315-325.

-26 Chu FF, Esworthy RS, Doroshow JH, Grasberger H, Donko A, Leto TL, Gao Q Shen B: Deficiency in Duox2 activity alleviates ileitis in GPx1- and GPx2-knockout mice without affecting apoptosis incidence in the crypt epithelium. Redox Biol 2016;11:144-156.

27 Kawahara T, Lambeth JD: Molecular evolution of Phox-related regulatory subunits for NADPH oxidase enzymes. BMC Evol Biol 2007;7:178.

28 Jones RM, Luo L, Ardita CS, Richardson AN, Kwon YM, Mercante JW, Alam A, Gates CL, Wu H, Swanson PA, Lambeth JD, Denning PW, Neish AS: Symbiotic lactobacilli stimulate gut epithelial proliferation via Noxmediated generation of reactive oxygen species. EMBO J 2013;32:3017-3028.

-29 Kato M, Marumo M, Nakayama J, Matsumoto M, Yabe-Nishimura C, Kamata T: The ROS-generating oxidase Nox1 is required for epithelial restitution following colitis. Exp Anim 2016;65:197-205.

-30 Matsumoto M, Katsuyama M, Iwata K, Ibi M, Zhang J, Zhu K, Nauseef WM, Yabe-Nishimura C: Characterization of N-glycosylation sites on the extracellular domain of NOX1/NADPH oxidase. Free Radic Biol Med 2014;68:196-204.

-31 Bae YS, Choi MK, Lee WJ: Dual oxidase in mucosal immunity and host-microbe homeostasis. Trends Immunol 2010;31:278-287.

-32 Harper RW, Xu C, McManus M, Heidersbach A, Eiserich JP: Duox2 exhibits potent heme peroxidase activity in human respiratory tract epithelium. FEBS Lett 2006;580:5150-5154.

33 Singel KL, Segal BH: NOX2-dependent regulation of inflammation. Clin Sci (Lond) 2016;130:479-490.

-34 Bedard K, Krause KH: The NOX family of ROS-generating NADPH oxidases: physiology and pathophysiology. Physiol Rev 2007;87:245-313.

-35 Wang R, Dashwood WM, Nian H, Löhr CV, Fischer KA, Tsuchiya N, Nakagama H, Ashktorab H, Dashwood RH: NADPH oxidase overexpression in human colon cancers and rat colon tumors induced by 2-amino-1methyl-6-phenylimidazo [4, 5-b]pyridine (PhIP). Int J Cancer 2011;128:2581-2590.

-36 Bauer KM, Hummon AB, Buechler S: Right-side and left-side colon cancer follow different pathways to relapse. Mol Carcinog 2012;51:411-421. 


\section{Cellular Physiology Cell Physiol Biochem 2018;50:2272-2282 \begin{tabular}{l|l|l} 
DOl: 10.1159/000495087 & $\begin{array}{l}\text { O } 2018 \text { The Author(s). Published by S. Karger AG, Basel } \\
\text { www.karger.com/cpb }\end{array}$
\end{tabular} \\ Xuan et al.: Role of Cyp4a14 in Colitis}

-37 Holla VR, Adas F, Imig JD, Zhao X, Price E Jr, Olsen N, Kovacs WJ, Magnuson MA, Keeney DS, Breyer MD, Falck JR, Waterman MR, Capdevila JH: Alterations in the regulation of androgen-sensitive Cyp 4a monooxygenases cause hypertension. Proc Natl Acad Sci U S A 2001;98:5211-5216.

38 Zhou Y, Yu J, Liu J, Cao R, Su W, Li S, Ye S, Zhu C, Zhang X, Xu H, Chen H, Zhang X, Guan Y: Induction of cytochrome P450 4A14 contributes to angiotensin II-induced renal fibrosis in mice. Biochim Biophys Acta 2018;1864:860-870.

39 Jackson LN, Zhou Y, Qiu S, Wang Q Evers BM: Alternative medicine products as a novel treatment strategy for inflammatory bowel disease. Am J Chin Med 2008;36:953-965.

-40 Esworthy RS, Kim BW, Larson GP, Yip ML, Smith DD, Li M, Chu FF: Colitis locus on chromosome 2 impacting the severity of early-onset disease in mice deficient in GPX1 and GPX2. Inflamm Bowel Dis 2011;17:13731386.

-41 Chu FF, Esworthy RS, Chu PG, Longmate JA, Huycke MM, Wilczynski S, Doroshow JH: Bacteria-induced intestinal cancer in mice with disrupted Gpx1 and Gpx2 genes. Cancer Res 2004;64:962-968.

-42 Untergasser A, Cutcutache I, Koressaar T, Ye J, Faircloth BC, Remm M, Rozen SG: Primer3--new capabilities and interfaces. Nucleic Acids Res 2012;40:e115.

43 Muller DN, Schmidt C, Barbosa-Sicard E, Wellner M, Gross V, Hercule H, Markovic M, Honeck H, Luft FC, Schunck WH: Mouse Cyp4a isoforms: enzymatic properties, gender- and strain-specific expression, and role in renal 20-hydroxyeicosatetraenoic acid formation. Biochem J 2007;403:109-118.

44 Capdevila JH, Falck JR, Harris RC: Cytochrome P450 and arachidonic acid bioactivation. Molecular and functional properties of the arachidonate monooxygenase. J Lipid Res 2000;41:163-181.

\45en H, Östman J, Bubb KJ, Panayiotou C, Priestley JV, Baker MD, Ahluwalia A: 20-Hydroxyeicosatetraenoic acid (20-HETE) is a novel activator of transient receptor potential vanilloid 1 (TRPV1) channel. J Biol Chem 2012;287:13868-13876.

-46 Kroetz DL, Xu F: Regulation and inhibition of arachidonic acid omega-hydroxylases and 20-HETE formation. Annu Rev Pharmacol Toxicol 2005;45:413-438.

47 Lakhkar A, Dhagia V, Joshi SR, Gotlinger K, Patel D, Sun D, Wolin MS, Schwartzman ML, Gupte SA: 20-HETE-induced mitochondrial superoxide production and inflammatory phenotype in vascular smooth muscle is prevented by glucose-6-phosphate dehydrogenase inhibition. Am J Physiol Heart Circ Physiol 2016;310:H1107-H1117.

48 Sobocanec S, Balog T, Sarić A, Sverko V, Zarković N, Gasparović AC, Zarković K, Waeg G, Macak-Safranko Z, Kusić B, Marotti T: Cyp4a14 overexpression induced by hyperoxia in female CBA mice as a possible contributor of increased resistance to oxidative stress. Free Radic Res 2010;44:181-190.

49 Coant N, Ben Mkaddem S, Pedruzzi E, Guichard C, Tréton X, Ducroc R, Freund JN, Cazals-Hatem D, Bouhnik Y, Woerther PL, Skurnik D, Grodet A, Fay M, Biard D, Lesuffleur T, Deffert C, Moreau R, Groyer A, Krause $\mathrm{KH}$, Daniel F, Ogier-Denis E: NADPH oxidase 1 modulates WNT and NOTCH1 signaling to control the fate of proliferative progenitor cells in the colon. Mol Cell Biol 2010;30:2636-2650.

-50 Lam G, Apostolopoulos V, Zulli A, Nurgali K: NADPH oxidases and inflammatory bowel disease. Curr Med Chem 2015;22:2100-2109. 